\title{
REFORMING THE NATIONAL MECHANISM OF ADMINISTRATIVE LIABILITY FOR ILLEGAL FUEL TRADE
}

The article is focused on the research of the directions for reforming the national legislation in the sphere of introduction of administrative liability for illegal trade in fuel.

The methodological basis of the presented scientific work is the systematic approach and systematic analysis.

The authors have offered understanding of the main components of the author's mechanism of administrative liability: the legal norm establishing liability, its legal composition, the subject of application of the norm and its procedure.

The authors have analyzed specific features of fuel as a specific subject of administrative and legal protection caused by its relation to the group of excisable goods. The qualifying features of illegal trade in fuel, their correlation with the available corpus delicti of offenses under the Code of Ukraine on Administrative Offenses have been studied.

The emphasis has been placed on the issue of bringing to administrative liability for illegal fuel trade. Particular attention has been paid to the shortcomings of the objective aspect of a number of offenses (articles 160, 161, 164 of the Code of Ukraine on Administrative Offenses).

Thus, it has been emphasized that the main disadvantage of applying the art. 160 of the Code of Ukraine on Administrative Offenses (sale "from hands" in the places not established for this purpose) is the inconsistency of its objective aspect with the common actions of the offender, when the illegal sale of fuel is carried out in the prescribed place, but without the necessary permits.

In turn, the disposition of the art. 161 of the Code of Ukraine on Administrative Offenses (illegal supply or purchase of gasoline or other fuels and lubricants) covers only the illegal supply or purchase of gasoline or other fuels and lubricants belonging to state or public enterprises, institutions and organizations, without features of embezzlement. Due to the above, its provisions cannot be applied during the circulation of fuel belonging to individuals.

Similarly, the main disadvantage of the application of the art. 164 of the Code of Ukraine on Administrative Offenses (violation of the procedure of economic activity) while illegal sale of fuel, there is a need to prove the regularity of such activities, i. e. its implementation at least three times a year.

To confirm this position, the authors have analyzed and presented court practice, with the reference to the Unified State Register of Court Decisions.

To solve the outlined problems, it has been offered to supplement the Code of Ukraine on Administrative Offenses with a new norm that provides administrative liability for the violation of the established procedure for fuel trade - the art. 161-1 of the Code of Ukraine on Administrative Offenses. The objective aspect of this offense should cover one-time actions related to the facts of illegal sale of fuel without the necessary permits (like the disposition of the art. 156 of the Code of Ukraine on Administrative Offenses, which provides liability for the sale of other excisable goods (alcohol and tobacco) without appropriate permits).

Key words: fuel, excise tax, liability, illegal sale, economic activity. 


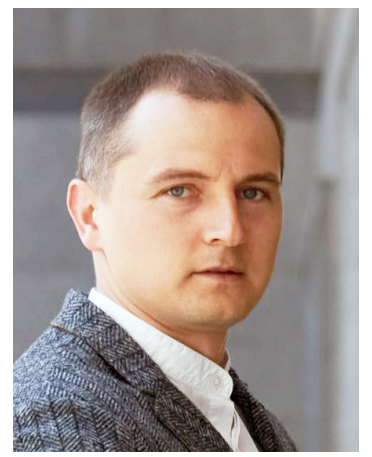

Dmytro Pryputen, Professor of General Legal Disciplines Department of Dnipropetrovsk State University of Internal

Affairs,

Doctor in Law, Associate

Professor

orcid.org/0000-0001-8519-8041

d.pryputen@gmail.com

\section{Denys Holoborodko,} Assistant Professor of Administrative

Law, Procedure and Administrative Activity Department of Dnipropetrovsk State University of Internal Affairs, PhD in Law, Associate Professor orcid.org/0000-0001-7441-9646 6326060@gmail.com

\section{Introduction}

The urgent issue in the field of national security is Ukraine's energy independence within the current conditions of globalization changes, existing hybrid military conflicts and shortages of hydrocarbons in the world.

Having a great potential in nuclear energy, rapid development of renewable energy sources, we face a certain shortage of hydrocarbon fuel, which increases our dependence on foreign imports and the need to effectively develop our own production, processing, establishing a clear and transparent state supervision over the fuel and energy sphere's administration.

The administration of fuel sales at the national market occupies the special place in the outlined vector, which is the key factor for ensuring both energy security of the state and filling the revenues of the State Budget - the financial heart of the country.

Thus, the excise tax belongs to national taxes in accordance with the art. 9 of the Tax Code of Ukraine, which is the indirect tax on the consumption of certain types of goods (products) and is included in the price of such goods ${ }^{1}$. Such excise goods include, in particular, fuel and goods (products) used as fuel for refueling vehicles, equipment or devices with internal combustion engines.

Unfortunately, it should be noted that there is current situation when a number of entrepreneurs deliberately violate the established procedure for fuel trade, evade the necessary permits and sell fuel without paying excise tax. As a result of such illegal actions, we observe that the State Budget, the consumer (buyer) of fuel, the local community, etc. are afflicted.

It is the reason that the issues of combating illegal fuel trade attract special attention from public authorities, law enforcement agencies, etc.

\section{Other research of the problem}

It should be noted that administrative and tort science has certain gaps in this direction. Thus, a number of studies are focused on the general issues of administrative liability

\footnotetext{
${ }^{1}$ Verkhovna Rada of Ukraine (2010). Tax Code of Ukraine: Law of Ukraine dated from December 02, 2010 № 2755-VI. URL: https://zakon.rada.gov.ua/rada/show/2755-17 [Податковий кодекс України : Закон України від 2 грудня 2010 р. № 2755-VI / Верховна Рада України. URL: https://zakon.rada.gov.ua/rada/ show/2755-17] (access date May 10, 2020).
} 
for the violation of the established procedure for conducting entrepreneurship (the art. 164 of the Code of Ukraine on Administrative Offenses), and on the other hand on the issues of administrative and commercial liability of taxpayers, etc.

In turn, the problematic issue of administrative liability for illegal fuel trade was not studied enough, except for fragmentary positions in the aspect of administration of excise goods.

This is primarily due to the imperfection of national legislation in this area and the lack of direct legal norms that can introduce an effective mechanism of administrative liability.

The objective of the study. Thus, trying to correct the existing gap of scientific attention to the issue of administrative liability for illegal fuel trade, the objective of this study will be legal analysis of the chosen direction, search for new approaches and development of propositions to improve national legislation in part of implementing effective legal tools to address existing problems in this area.

Research methods. A number of methods of scientific cognition have been used in the process of research. First of all, by using the method of system approach, the author has offered own model of constructing the mechanism of administrative liability.

In turn, the method of systematic analysis allowed the author of the research to analyze the existing law enforcement court practice of bringing a person to administrative liability, to distinguish the main shortcomings and, on this basis, to offer own view on lawmaking directions.

\section{Main part}

At the beginning of the analysis it is necessary to conduct the detailed research how is the mechanism of administrative liability for illegal fuel trade built now?

As one knows, the mechanism of bringing to administrative liability should be understood as a set of interrelated measures of material and technical, organizational and managerial, special and legal nature, carried out by public authorities and their officials and are intended to ensure administrative prosecution of perpetrators ${ }^{2}$.

We can distinguish the main parts of such a mechanism? This mechanism includes:

- legal norm that establishes administrative liability;

- legal composition of an offense (subject, object, subjective and objective aspects of an offense);

- leading subject of applying legal norm;

- procedure of applying liability (including, application of measures of ensuring proceedings in cases on administrative offenses).

That is, a simple classical formula of the model of administrative liability mechanism is demonstrated: a norm - offense - subject of the norm's application - procedure.

We offer to consider separately the components of this model.

A detailed analysis of the provisions of the Code of Ukraine on Administrative Offenses (hereinafter - CUAO) allows us to conclude that there are at least three

\footnotetext{
${ }^{2}$ Belikova, O.V. (2013). The mechanism of implementing measures of administrative responsibility for violations in land relations in Ukraine. Administrative law and process, no. 4(6), pp. 132-139 [Бєлікова О.В. Механізм реалізації заходів адміністративної відповідальності за правопорушення в сфері земельних відносин в Україні. Адміністративне право і процес. 2013. № 4(6). C. 132-139].
} 
types of administrative offenses that may cover the raised issue: part 1 of the art. 160, the art. 161 and the art. 164 of the CUAO.

Let's consider each of them separately and focus on the problems of their application in case of illegal sale of fuel.

Part 1 of the art. 160 of the CUAO stipulates administrative liability for sale "from hands", sale of industrial goods, sale in the places not established for this purpose. That is, the objective aspect of the offense covers actions related to the sale of goods that are manufactured industrially and the commission of such actions in places where this sale is strictly prohibited.

For the most part, citizens are prosecuted for this offense for one-time, episodic cases of selling small goods on the streets, squares, etc., which violates the established order of trade, creates inconvenience to citizens, spoils the overall picture of a modern, tidy city.

But the application of this norm in case of illegal sale of fuel is problematic from the standpoint that the "excise" of the goods sold, the possible negative impact on safety and environmental status. One should agree that spilling milk or sunflower oil is, for example, less harmful to the environment than spilling fuel oil or diesel fuel.

Besides, the objective aspect of this offense provides the mandatory presence of a prohibited place of sale (streets, squares, courtyards, porches, etc.). In reality, the sale of fuel more often takes place in equipped places of sale at gas stations, but without the presence of statutory permits.

Thus, it is logical to conclude about the erroneousness and inappropriateness of the qualification of such actions under the art. 160 of the CUAO.

The second possible legal qualification of the considered tort actions is the art. 161 of the CUAO (illegal supply or purchase of gasoline or other fuels and lubricants), which provides administrative liability for illegal supply or purchase of gasoline or other fuels and lubricants belonging to state or public enterprises, institutions and organizations, in the absence of embezzlement features.

Problematic aspect of legal enforcement of this norm is its outright obsolescence. Thus, the objective aspect of this offense includes the mandatory presence of the subject matter of the offense - fuel belonging to state or public entities. Thus, the narrowing of the objective aspect of the offense precludes its application during the sale of fuel belonging to private entities, including citizens.

The third option for the qualification of the analyzed illegal actions is to bring the offender to administrative liability under part 1 of the art. 164 of the CUAO (violation of the procedure for conducting economic activity).

The specified legal norm is rather voluminous, universal and can be applied to the considered legal relations if there are certain conditions. But it is only at the first glance.

Despite the broad objective aspect of this offense, which makes it possible to apply it during various actions of the subject (not only the sale of fuel, but also the implementation of transportation, construction, trade in various goods, other economic activities, etc.), it contains certain flaws that influence its purpose - universality.

Thus, in a detailed analysis of the objective aspect of the offense (the art. 164 of the CUAO - authors' note), we can identify its significant structural shortcomings, which in many cases makes it impossible for its controlling entities. 
Part 1 of the art. 164 of the Code of Ukraine on Administrative Offenses provides liability for:

- carrying out economic activity by a citizen without state registration as a business entity;

- carrying out economic activity by a citizen without submitting a notice of commencement of economic activity, if the obligation to submit such a notice is provided by law;

- carrying out economic activity by a citizen without obtaining a license to conduct this type of economic activity that is the subject to licensing in accordance with the law;

- carrying out economic activity by a citizen during the period of suspension of the license, if the legislation does not provide the conditions of conducting license activity during the period of suspension of the license;

- carrying out economic activity by a citizen without obtaining a permit, if its receipt is provided by law (except cases of applying the principle of tacit consent) ${ }^{3}$.

Administrative liability arises in the presence of at least one of the listed illegal actions.

But the main problem of the application of part 1 of the art. 164 of the CUAO during the qualification of actions on illegal sale of fuel, is existence of the objective aspect's construction of an offense of the category of "economic activity" in a design party.

According to the provisions of the Commercial Code of Ukraine, economic activity means the activities of economic entities in the field of social production, aimed at manufacturing and selling products, performing works or providing services of a cost nature that have a price.

In turn, economic activity carried out to achieve economic and social results and for getting profit is considered entrepreneurship, and business entities - as entrepreneurs ${ }^{4}$.

Further legal analysis of the provisions of the Commercial Code of Ukraine allows us to conclude that the current national legislation considers entrepreneurship as an independent, proactive, systematic, implemented by the entity at its own risk economic activities carried out by business entities (entrepreneurs) in order to achieve economic and social results and profit (the art. 42 of the Commercial Code of Ukraine).

Thus, entrepreneurial activity is one of the types of economic activity, a mandatory feature of which is, in particular, the regularity of its implementation in order to make a profit.

It is the feature of systematic activity of the subject is the main sticking point, which, in many cases, prevents the offender from being prosecuted.

${ }^{3}$ Verkhovna Rada of the Ukrainian Soviet Socialist Republic (1984). Code of Ukraine on Administrative Offenses: Law of Ukraine dated from December 07, 1984 № 8073-X. URL: https://zakon.rada.gov.ua/laws/show/80731-10/ed20200514 [Кодекс України про адміністративні правопорушення : Закон України від 7 грудня 1984 р. № 8073-Х / Верховна Рада Української Радянської Соціалістичної Республіки. URL: https://zakon.rada.gov.ua/laws/ show/80731-10/ed20200514] (access date May 10, 2020).

${ }^{4}$ Verkhovna Rada of Ukraine (2003). Commercial Code of Ukraine: Law of Ukraine dated from January 16, 2003 № 436-IV. URL: https://zakon.rada.gov.ua/laws/show/436-15 [Господарський кодекс України : Закон України від 16 січня 2003 р. № 436-IV / Верховна Рада України. URL: https://zakon.rada.gov.ua/laws/show/436-15] (access date May 10, 2020). 
Analysis of law enforcement court practice allows us to conclude that there is currently a stable model of understanding the features of systematic activity, as its implementation at least three times in one calendar year (resolution of the Plenum of the Supreme Court of Ukraine "On the practice of application of legislation on liability for certain crimes in the sphere of economic activity" dated from April 25, 2003 № 3)

Thus, one of the main points to be proved during the prosecution under part 1 of the art. 164 of the CUAO are the repeated facts of selling fuel by the guilty party. This feature of the component of proving the illegality of the offender's actions requires the authorized entity to perform long and similar actions related to the fixation of three cases of fuel sales. In turn, single and double cases of fuel sales are not covered at all by the objective aspect of part 1 of the art. 164 of the CUAO.

For example, the case on administrative offense under part 1 of the art. 164 of the CUAO was closed because of the absence of corpus delicti of administrative offense in actions of the person in accordance with the decision of the Chernihiv District Court of Chernihiv region dated from December 12, 2019 in the case № 748/2958/19.

In particular, the court noted: "Considering the provided evidence, explanations PERSON_1, lack of data on the sale of diesel fuel and systematic implementation of such economic activities, the court concludes that the actions of PERSON_1 did not have corpus delicti of administrative offense under part 1 of the art. 164 of the CUAO"6.

Similar conclusions were made by the courts during the consideration of other cases: № 283/916/20 (Malynskyi District Court of Zhytomyr region), № 644/203/20 (Ordzhonikidzevskyi District Court of Kharkiv City) ${ }^{8}$, № 601/646/19 (Kremenetskyi District Court of Ternopil region) ${ }^{9}$, etc.

${ }^{5}$ Supreme Court of Ukraine (2003). On the practice of courts application of the legislation on liability for certain crimes in the economic sphere: Resolution of the plenum of the Supreme Court of Ukraine dated from April 25, 2003 № 3. URL: https://zakon.rada.gov.ua/laws/show/ va003700-03 [Про практику застосування судами законодавства про відповідальність за окремі злочини у сфері господарської діяльності : Постанова Пленуму Верховного Суду України від 25 квітня 2003 р. № 3 / Верховний Суд України. URL: https://zakon.rada.gov.ua/ laws/show/va003700-03] (access date May 10, 2020).

${ }^{6}$ Chernihiv District Court of the Chernihiv Region (2019). Resolution of the Chernihiv District Court of the Chernihiv Region dated from December 12, 2019 in the case № 748/2958/19. URL: http://reyestr.court.gov.ua/Review/86297050 [Постанова Чернігівського районного суду Чернігівської області від 12 грудня 2019 р. у справі № 748/2958/19. URL: http://reyestr.court. gov.ua/Review/86297050] (access date May 10, 2020).

${ }^{7}$ Malyn District Court of the Zhytomyr Region (2020). Resolution of the Malyn District Court of the Zhytomyr Region dated from May 04, 2020 in the case № 283/916/20. URL: http:// reyestr.court.gov.ua/Review/89041788 [Постанова Малинського районного суду Житомирської області від 4 травня 2020 р. у справі № 283/916/20. URL: http://reyestr.court.gov.ua/ Review/89041788] (access date May 10, 2020).

${ }^{8}$ Ordzhonikidze District Court of Kharkiv (2020). Resolution of the Ordzhonikidze District Court of Kharkiv dated from February 5, 2020 in the case № 644/203/20. URL: http://reyestr.court. gov.ua/Review/87444760 [Постанова Орджонікідзевського районного суду міста Харкова від 5 лютого 2020 р. у справі № 644/203/20. URL: http://reyestr.court.gov.ua/Review/87444760] (access date May 10, 2020).

${ }^{9}$ Kremenets District Court of Ternopil region (2019). Resolution of the Kremenets District Court of Ternopil region dated from April 16, 2019 in the case № 601/646/19. URL: http://reyestr. court.gov.ua/Review/81198440 [Постанова Кременецького районного суду Тернопільської 
Taking into account the above, it should be noted that the application of part 1 of the art. 164 of the CUAO, during illegal sale of fuel, demands from the subject to draw up the minutes on administrative offense of collecting corresponding and convincing evidence, which would testify to repeated (systematic) commission of the specified illegal actions by the perpetrator directed on getting profit from sale of fuel. A person's one-time (non-systematic) action related to the sale of fuel without permits provided by law (primarily license for the sale of fuel) or without state registration of the offender as a business entity is not covered by the objective aspect of part 1 of the art. 164 of the CUAO and does not constitute an administrative offense.

For the full analysis of the current norms establishing administrative liability for illegal sale of fuel, it is necessary to distinguish the possibility of applying administrative and economic sanctions to the perpetrator based on the provisions of the Law of Ukraine "On state regulation of production and circulation of ethyl, cognac and fruit alcohol, alcoholic beverages, tobacco products and fuel" dated from December 19, $1995^{10}$.

According to the art. 238 of the Commercial Code of Ukraine, administrative and economic sanctions are measures of organizational, legal or property nature, applied by authorized state authorities and local self-government agencies and aimed at stopping the offenses of business entities and eliminating their consequences. In accordance with part 2 of the art. 238 of the Commercial Code of Ukraine, the types of administrative and economic sanctions, conditions and procedure for their application are determined by the Commercial Code of Ukraine, other legislative acts, and the sanctions themselves can be established only by laws ${ }^{11}$.

Part 2 of the art. 17 of the Law of Ukraine "On state regulation of production and circulation of ethyl, cognac and fruit alcohol, alcoholic beverages, tobacco products and fuel" provides that financial sanctions are applied to business entities (including foreign entities operating through their registered permanent establishments) in the form of fines in case of wholesale or retail trade in fuel without a license.

Decisions on the application of administrative and economic sanctions for fuel trading without obtaining a license are made by the agencies of the State Fiscal Service.

Illegal trade in fuel is often carried out by individuals who deliberately do not register as business entities in order to avoid imposing significant financial sanctions. Based

області від 16 квітня 2019 р. у справі № 601/646/19. URL: http://reyestr.court.gov.ua/ Review/81198440] (access date May 10, 2020).

${ }^{10}$ Verkhovna Rada of Ukraine (1995). On state regulation of production and circulation of ethyl, cognac and fruit alcohol, alcoholic beverages, tobacco products and fuel: Law of Ukraine dated from December 19, 1995 № 481/95-BP. URL: https://zakon.rada.gov.ua/laws/show/481/95$\% \mathrm{D} 0 \% \mathrm{~B} 2 \% \mathrm{D} 1 \% 80$ [Про державне регулювання виробництва і обігу спирту етилового, коньячного і плодового, алкогольних напоїв, тютюнових виробів та пального : Закон України від 19 грудня 1995 р. № 481/95-BP / Верховна Рада України. URL: https://zakon. rada.gov.ua/laws/show/481/95-\%D0\%B2\%D1\%80] (access date May 10, 2020).

${ }^{11}$ Kulyk, O.I. (2019). Administrative and commercial sanctions for the violations in the sphere of the use of energy from renewable sources. Scientific Bulletin of Uzhhorod National University. Series “Law”, issue 56, vol. 1, pp. 113 [Кулик O.I. Адміністративно-господарські санкції за порушення в сфері використання альтернативних джерел енергії. Науковий вісник Ужгородського національного університету. Серія «Право». 2019. Вип. 56. Т. 1. C. 113-118]. 
on the legal nature and purpose of administrative and economic sanctions, it can be concluded that they are only applied to business entities (individuals - entrepreneurs or legal entities). Thus, the application of the provisions of the art. 17 of the Law of Ukraine "On state regulation of production and circulation of ethyl, cognac and fruit alcohol, alcoholic beverages, tobacco products and fuel" to individuals - citizens who are not registered as business entities - is not provided.

Studying the aspect of application of administrative and economic sanctions for fuel trade without obtaining a license, it is necessary to analyze the debatable issue of double liability of the subject.

An authorized entity (the State Fiscal Service of Ukraine) often executes the minutes on administrative offenses under part 1 of the art. 164 of the CUAO with a similar plot of an offense (trade in fuel without the license) during the detection of illegal facts of fuel trade, besides the application of administrative and economic sanction (fine) against the violator in accordance with part 2 of the art. 17 of the Law of Ukraine "On state regulation of production and circulation of ethyl, cognac and fruit alcohol, alcoholic beverages, tobacco products and fuel".

In our opinion, the specified algorithm of actions of the authorized subjects is wrong and is not based on the norms of the art. 61 of the Constitution of Ukraine, according to which no one can be twice prosecuted of the same type for the same offense.

We believe that the very provision of part 2 of the art. 17 of the Law № 481 should be applied in these legal relations, as a special norm, and the proceedings in the case on administrative offense are subject to closure on the basis of paragraph 8 of the art. 247 of the CUAO (existence of the resolution of the competent agency (an official) on the same fact concerning the person who is brought to administrative liability, on imposing an administrative penalty).

Court practice in these cases is on similar positions (decision of Zhovtovodsk City Court of Dnipropetrovsk region dated from November 13, 2019, case № 176/2113/19) ${ }^{12}$.

Officials of the State Fiscal Service of Ukraine and the National Police occupy the major place among the main subjects of exercising liability for the illegal sale of fuel. It is the above-mentioned persons who are empowered by law to draw up the minutes on administrative offenses (in particular, under part 1 of the art. 164 of the CUAO). Besides, as noted above, the agencies of the State Fiscal Service of Ukraine, endowed with the competence to apply administrative and economic sanctions under part 2 of the art. 17 of the Law № 481 .

In accordance with the provisions of the art. 265 of the CUAO, these entities have the right, at the stage of administrative investigation, to use, as a measure of ensuring the proceedings, the procedure of seizure of items that are tools or direct objects of the offense: fuel, storage tanks, fuel dispensers, money received from sales, documents, etc.

\footnotetext{
${ }^{12}$ Zhovtovodsk City Court of Dnipropetrovsk (2019). Resolution of the Zhovtovodsk City Court of Dnipropetrovsk region dated from November 13, 2019 in the case № 176/2113/19. URL: http://reyestr.court.gov.ua/Review/85687003 [Постанова Жовтоводського міського суду Дніпропетровської області від 13 листопада 2019 р. у справі № 176/2113/19. URL: http://reyestr.court.gov.ua/Review/85687003] (access date May 10, 2020).
} 
The leading subject in the consideration of cases of administrative offenses for illegal trade in fuel is the court (the art. 221 of the CUAO). The provisions of the Code impose on the court the right to make decisions in cases on administrative offenses in accordance with the art. 284 of the CUAO and making decisions on the fate of the seized items (confiscate or return to the owner).

It should be noted that in accordance with the provisions of the art. 29 of the CUAO, only property owned by the violator may be confiscated. Therefore, in case the violator uses the leased property (for example, fuel storage tanks) during illegal actions, these items cannot be confiscated by the court decision and are subject to return to their rightful owner.

\section{Conclusions}

Summarizing the above, it should be noted that the mechanism of administrative liability for illegal sale of fuel is characterized by a certain legislative inconsistency and legal imbalance.

The stated problems are caused by the lack of certain special norms that would establish administrative liability for cases of illegal sale of fuel.

In our opinion, the way for effective resolution of the highlighted problems is the introduction of a separate corpus delicti of administrative offense, the objective aspect of which would cover one-time actions related to the facts of illegal sale of fuel without the necessary permits. An example of building a successful objective aspect of the new corpus delicti of the offense may be the disposition of the art. 156 of the Code of Ukraine on Administrative Offenses, which provides liability for the sale of other excise goods (alcohol and tobacco) without the relevant permits.

The subject of a new offense should be not only a business entity, but also an individual who has reached the age of administrative liability, in accordance with the art. 12 of the Code of Ukraine on Administrative Offenses, and who operates without the state registration as a business entity.

For this purpose, the draft law № 2515 "On Amendments to the Code of Ukraine on Administrative Offenses to Strengthen Administrative Liability for Illegal Trade in Fuel" was registered in Verkhovna Rada of Ukraine on December 2, 2019.

This draft law, among the above propositions, provides supplementing the provisions of the Code of Ukraine on Administrative Offenses with a new legal corpus delicti of an administrative offense - the art. 161-1 "Violation of the procedure of trade in fuel"13.

Besides substantive legal norms, this draft law contains some provisions to adjust some procedural aspects of exercising administrative liability for the illegal sale of fuel.

Thus, it is offered to exclude the possibility of using the institutions of exemption from administrative liability due to the transfer of the case to the consideration of the labor

${ }^{13}$ Pryputen, D.S., Pavliuk, M.V. (initiat.) (2019). On amending the Code of Ukraine on Administrative Offenses in regard to strengthening administrative liability for illegal trade in fuel: Draft Law of Ukraine № 2515 dated from December 02, 2019. URL: http:// w1.c1.rada.gov.ua/pls/zweb2/webproc4_1?id=\&pf3511=67508 [Про внесення змін до Кодексу України про адміністративні правопорушення щодо посилення адміністративної відповідальності за незаконну торгівлю пальним : проект Закону України № 2515 від 2 грудня 2019 р. (ініціатори законопроекту: Д.С. Припутень, M.В. Павлюк). URL: http:// w1.c1.rada.gov.ua/pls/zweb2/webproc4_1?id=\&pf3511=67508] (access date May 10, 2020). 
collective (the art. 21 of the Code of Ukraine on Administrative Offenses) and due to insignificance (the art. 22 of the Code of Ukraine on Administrative Offenses) in case of illegal sale of fuel.

Besides, it is offered to amend the art. 265 of the Code of Ukraine on Administrative Offenses in order to preserve evidence of the offense and to ensure the realization of court decisions, which should establish direct prohibition of transfer of the withdrawn items and documents on storage to the person who is brought to administrative liability.

At the same time, the provisions of the draft law provide a long-expected decision to expand the subjective composition for appealing decisions in cases on administrative offenses. Thus, it is offered to give the right to appeal the decisions not only to the offender and the victim, but also to officials who exercised the minutes on administrative offenses. If the Parliament supports this initiative, the parties to administrative and tort proceedings (the person prosecuted and the subject of exercising the minutes as the actual party to the accusation) will acquire equal procedural rights and opportunities to initiate the appellate review procedure, which can strengthen both control over court actions of the first instance and the quality of rulings, as well as can reduce to some extent the impact of various corruption factors on the activities of judges.

\title{
РЕФОРМУВАННЯ НАЦІОНАЛЬНОГО МЕХАНІЗМУ АДМІНІСТРАТИВНОЇ ВІДПОВІДАЛЬНОСТІ ЗА НЕЗАКОННУ ТОРГІВЛЮ ПАЛИВОМ
}

\author{
Дмитро Припутень, \\ професор кафедри загальноправових дисциплін \\ Дніпропетровського державного університету внутрішніх справ, \\ доктор юридичних наук, доцент \\ orcid.org/0000-0001-8519-8041 \\ d.pryputen@gmail.com \\ Денис Голобородько, \\ доцент кафедри адміністративного права, процесу та адміністративної діяльності \\ Дніпропетровського державного університету внутрішніх справ, \\ кандидат юридичних наук, доцент \\ orcid.org/0000-0001-7441-9646 \\ 6326060@gmail.com
}

Стаття зосереджена на дослідженні напрямів реформування національного законодавства у сфері запровадження адміністративної відповідальності за незаконну торгівлю паливом. Методологічною основою представленої наукової роботи є системний підхід та систематичний аналіз.

Автори запропонували розуміння основних складників авторського механізму адміністративної відповідальності, якими є правова норма, щуо встановлює відповідальність, ї̈ правовий склад, предмет застосування норми та порядок ї̈ здійснення.

Автори проаналізували особливості палива як специфічного предмета адміністративно-правового захисту, спричиненого його відноменням до групи підакиизних товарів. Досліджено кваліфікуючі особливості незаконної торгівлі паливом, їх співвідномення 
з наявними складниками злочинів, передбачених Кодексом України про адміністративні правопорушення.

Акцеентовано увагу на питанні притягнення до адміністративної відповідальності за незаконну торгівлю паливом. Особлива увага приділяється недолікам об' 'ктивного аспекту низки правопорушень (ст. ст. 160, 161, 164 Кодексу Украӥни про адміністративні правопорушення).

Таким чином, підкреслено, щуо головний недолік застосування ст. 160 Кодексу Украйни про адміністративні правопорушення (продаж «з рук» у місиях, не встановлених для иісї мети) це невідповідність його об'єктивного аспекту загальним діям правопорушника, коли незаконний продаж пального здійснюється у призначене місие, проте без необхідних дозволів.

Своєю чергою диспозииія ст. 161 Кодексу України про адміністративні правопорушення (незаконне постачання або купівля бензину чи іншого палива та мастил) охоплює лише незаконне постачання або придбання бензину чи іншого палива й мастил, що належать державним або громадським підприємствам, установам та організаціям, без ознак розтрати. Через вищезазначене положення кодексу не можуть застосовуватися під час обігу палива, яке належить фізичним особам.

Також головним недоліком застосування ст. 164 Кодексу Украӥни про адміністративні правопорушення (порушення порядку господарської діяльності) під час незаконного продажу пального є те, щуо є необхідність довести закономірність такої діяльності, тобто ї̈ здійснення не рідше трьох разів на рік.

Для підтвердження иієї позииї автори проаналізували та подали практику суду з посиланням на Єдиний держсавний реєстр судових рішень.

Для вирішення окреслених проблем запропоновано доповнити Кодекс України про адміністративні правопорушення новою нормою, яка передбачатиме адміністративну відповідальність за порушення встановленого порядку торгівлі паливом, - cm. 161-1 Кодексу Украйни про адміністративні правопорушення. Об'єктивний аспект ияього правопорушення повинен охоплювати разові діï, пов'язані з фактами незаконного продажу пального без необхідних дозволів (наприклад, диспозиція ст. 156 Кодексу України про адміністративні правопорушення, яка передбачає відповідальність за продаж інших підакцизних товарів (алкоголю й тютюну) без відповідних дозволів).

Ключові слова: пальне, акцизний податок, відповідальність, незаконний продаж, господарська діяльність. 